Supporting Information (SI) for

\title{
Evaluating adsorption and biodegradation mechanisms during the removal of microcystin-RR by periphyton
}

\author{
YONGHONG WU ${ }^{*}$, JIANGZHOU HE $^{*}$ LINZHANG YANG ${ }^{*}, \dagger$ \\ ${ }^{\dagger}$ State Key Laboratory of Soil and Sustainable Agriculture, Institute of Soil Science, Chinese \\ Academy of Sciences $\quad$ No.71, East Beijing Rd, Nanjing 210008, P. R. China \\ ${ }^{\ddagger}$ College of Life Science, Tarim University, Shihezi Alar 843300, P. R. China \\ ${ }^{\S}$ Graduate University of Chinese Academy of Sciences, Beijing 100049, P. R. China \\ *Corresponding author: Dr. Yonghong Wu; Prof. Dr Linzhang Yang, Tel (Fax): \\ +86-25-86881591; E-mail: yhwu@issas.ac.cn (Y. Wu); lzyang@ issas.ac.cn (L. Yang)
}

\section{Contents (5 pages)}

1. The equations of sorption energy $(E)$ and Gibbs free energy ( $\square G^{o}$ )

2. The method for characterilizing the diversity of bacteria with flaA gene

3. The method for analyzing MCRR in water and periphyton

4. Figure 1S

5. Literature cited 


\section{The equations of sorption energy $(E)$ and Gibbs free energy $\left(\Delta G^{o}\right)$}

The mean sorption energy $E(\mathrm{~kJ} / \mathrm{mol})$ can be calculated using the following equation $(1,2)$.

$$
E=\frac{1}{\sqrt{2 \beta}}
$$

The Gibbs free energy $\left(\Delta G^{o}\right)$ was calculated from equilibrium constant value $\left(K_{\mathrm{L}}\right)$ following the equation:

$$
\Delta G^{\circ}=-R T \ln \left(K_{L}\right)
$$

\section{The method for characterilizing the diversity of bacteria with flaA gene}

$5.0 \mathrm{~g}$ of dried periphyton (86\% moisture content ) was placed into a centrifuge tube and centrifuged for 10 min. DNA was extracted from periphyton by the method provided by Di

Giovanni et al. (3). PCR amplification of the flaA gene was performed using the forward oligonucleotide primer (5'AGCTCTTAGCTCCATGAGTT3') and the reverse primer (5'ACATTGTAGCTAAGGCGACT 3') (4, 5). For ERIC-PCR, the forward primer (5'-ATGTAAGCTCCTGGGGA-TTCAC-3') and the reverse primer (5'-AAGTAAGTGACTGGGG-TGAGCG) were used (6). Reactions were performed in a 50 $\mu \mathrm{L}$ volume in a Perkin Elmer thermocycler (Gene Amp PCR System 2,400). Reaction mixtures contained $1 \mu \mathrm{M}$ of each primer, 50 to $100 \mathrm{ng}$ of genomic DNA, $1.5 \mathrm{mM} \mathrm{MgCl}_{2}$, each deoxynucleoside triphosphate (dATP, dTTP, dCTP, dGTP; Promega, USA) at a concentration of $0.2 \mathrm{mM}$, and $1 \mathrm{U}$ of Taq DNA polymerase (Promega, USA). For flaA amplification, cycle conditions of 1 cycle at $94{ }^{\circ} \mathrm{C}$ for $2 \mathrm{~min} ; 35$ cycles of $94{ }^{\circ} \mathrm{C}$ for $1 \mathrm{~min}, 65{ }^{\circ} \mathrm{C}$ for $30 \mathrm{~s}$, and 72 ${ }^{\circ} \mathrm{C}$ for $30 \mathrm{~s}$; and 1 cycle at $72{ }^{\circ} \mathrm{C}$ for 10 min were used. For ERIC-PCR, the amplification was 
accomplished by running 30 cycles of denaturing at $90{ }^{\circ} \mathrm{C}$ for $30 \mathrm{~s}$, annealing at $50{ }^{\circ} \mathrm{C}$ for $30 \mathrm{~s}$ and extending at $50{ }^{\circ} \mathrm{C}$ for $30 \mathrm{~s}$, and the initial denaturing at $95^{\circ} \mathrm{C}$ for $5 \mathrm{~min}$, initial extending at $72{ }^{\circ} \mathrm{C}$ for $8 \mathrm{~min}$. All amplification products were electrophoresized in agarose gels, stained with ethidium bromide, detected under a short-wavelength UV light source, and photographed with a Polaroid 667 camera. The 100 bp DNA Ladder (Promega) was used as a molecular size marker. The Shannon-Weaver diversity index (7) of bacteria carrying flaA gene in periphyton was calculated based on the relative area of ERIC-PCR fingerprint peak.

\section{The method for analyzing MCRR in water and periphyton}

A high-performance liquid chromatograph with a UV detector was used for MCRR analysis. The system consisted of a Waters 600 pump, a 600E controller and a 2487 dual $1 \mathrm{UV}-\mathrm{Vis}$ detector. Separation was accomplished under a reversed-phase isocratic condition with a Delta-pak $\mathrm{C}_{18}$ column $(150 \times 3.9 \mathrm{~mm}$, Waters $)$ and a mobile phase of methanol $(0.01 \%$ TFA

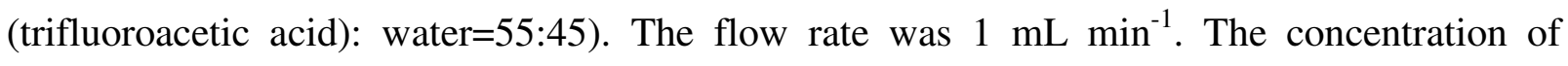
MCRR was determined by comparing the peak area at $238 \mathrm{~nm}$ with that of the MCRR standard. Standards of MCRR were purchased from Sigma Co. (Japan). All solvents and chemicals used in this study were HPLC or analytical grade. Double-distilled water was used throughout, and its conductivity at room temperature was ranged from $0.20 \mu \mathrm{S} \mathrm{m}^{-1}$ to $0.60 \mu \mathrm{S}$ $\mathrm{cm}^{-1}$. The MCRR in periphyton was extracted using $75 \%$ methanol, according to the method described by Fastner et al. (8).

\section{Figure $1 S$}




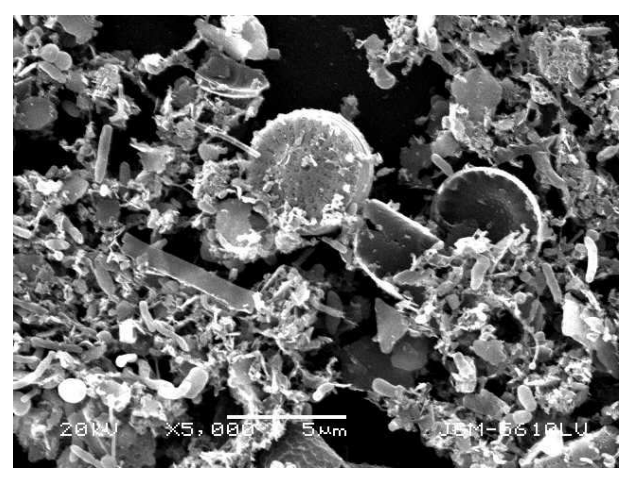

(a)

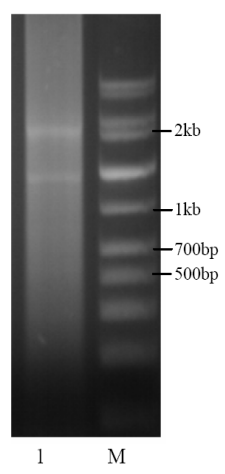

(b)

Figure 1. (a) The SEM image of periphyton using for removing MCRR; and (b) ERIC-PCR fingerprint of bacteria of flaA gene. The reference bands are on the right (M) and the sample bands are on the left (1).

\section{Literature Cited}

(1) Benhammou, A.; Yaacoubi, A.; Nibou, L.; Tanouti, B., Adsorption of metal ions onto Moroccan stevensite: kinetic and isotherm studies. J. Colloid Interf. Sci. 2005, 282 (2), $320-326$.

(2) El-Shahawi, M. S.; Nassif, H. A., Retention and thermodynamic characteristics of mercury(II) complexes onto polyurethane foams. Anal. Chim. Acta 2003, 481 (1), 29-39.

(3) Di Giovanni, G. D.; Watrud, L. S.; Seidler, R. J.; Widmer, F., Fingerprinting of mixed bacterial strains and BIOLOG gram-negative (GN) substrate communities by enterobacterial repetitive intergenic consensus sequence-PCR (ERIC-PCR). Curr. Microbiol. 1999, 38 (4), 217-223.

(4) Dons, L.; Rasmussen, O. F.; Olsen, J. E., Cloning and characterization of a gene encoding flagellin of Listeria monocytogenes. Mol. Microbiol. 1992, 6 (20), 2919-2929. 
(5) Gray, D. I.; Kroll, R. G., Polymerase chain reaction amplification of the flaA gene for the rapid identification of Listeria spp. Lett. Appl. Microbiol. 1995, 20 (1), 65-68.

(6) Jersek, B.; Giltot, P.; Gubina, M.; Klun, N.; Mehle, J.; Tcherneva, E., Typing of Listeria monocytogenes strains by repetitive element sequence-based PCR. J. Clin. Microbiol. 1999, 37 (7), 103-109.

(7) Weaver, W.; Shannon, C. E., The Mathematical Theory of Communication. Urbana, Illinois: University of Illinois Press, republished in paperback. 1949.

(8) Fastner, J.; Flieger, I.; Neumann, U., Optimised extraction of microcystins from field samples -- a comparison of different solvents and procedures. Water Res. 1998, 32 (10), 3177-3181. 